doi: 10.17492/manthan.v3i2.7875

\title{
Entrepreneurial Opportunities for Persons with Disabilities
}

\author{
Bhuvaneswari. $R^{*}$ and P. Natarajan**
}

\begin{abstract}
Promoting entrepreneurship at the grass root level is the need of the hour, especially for the people who are so far excluded in the growth process, i.e., person with disabilities $(P W D s)$. Basically disabled persons have been found to have an inherent quality of strong determination and the will power to withstand challenges. However, sometimes environmental aspects are not motivating or facilitating them in a proper perspective. In the case of South India, while government's pro-entrepreneurship policies, together with private sector interventions are having an impact, yet disabled persons in rural and remote south India are still constrained by societal prejudices, financial limitations, and limited entrepreneurship educational opportunities. The purpose of this study is to explore the entrepreneurial opportunities for PWDs. As such, the study addresses an important literature gap concerning differently abled entrepreneurship. This paper focuses on the role of NHFDC and Ministry of Social Justice and Empowerment in promoting entrepreneurship among different abled persons.
\end{abstract}

Keywords: Self-employment opportunity; Entrepreneurship; Environmental support; Disabilities; Empowerment.

\subsection{Introduction}

Entrepreneurship development is a collection of people's activities and behaviours which incorporates chance identification and exploitation, creative thinking and worth creation. It means the entrepreneurs and their activities mainly help competitiveness improvement, job creation, economic development and value and new wealth creation (Karimi and Mobaraki, 2012).

\footnotetext{
*Doctoral Scholar, Department of Commerce, School of Management, Pondicherry University, Puducherry. (e-mail: rtbhuvaneswari@gmail.com)

**Professor and Head, Department of Commerce, School of Management, Pondicherry University, Puducherry (e-mail: natarajanppu@gmail.com)
} 
Different abled people tend to be concentrated in lower-skilled, lower-paid occupations and low entrepreneurship participation. Its rates are costly for the individuals concerned in terms of economic and psychological well-being, for governments in terms of lost output and tax revenues, and increased welfare payments for society in terms of the impact of social exclusion and discrimination on civic participation and public life. One possible solution to problems of low participation rates lies in the potential for disabled people to become self-employed or to start and run their own businesses (Meager and Higgins, 2011). The self-employment can be used as a potential rehabilitation vocational tool to achieve faster and better integration into the labour market of individuals who are disabled (Arnold and Seekins, 2002). Today's realities indicate that there it is difficult for the government of any country to provide jobs to absorb all graduates from the tertiary institutions. This means that, there is the need for a change in the mindset of disabled graduates from the look for a job syndrome to create a job mentality in order to actualise their educational aspirations (Johnmark et al, 2016).

\subsection{Review of Literature}

Many empirical studies have been done on different issues of disabled entrepreneurs. Some of these studies concentrate in the field of person with disabilities (PWDs) entrepreneur's theory particularly on the relevancy of schemes and policies of social welfare offices in that particular state/country. In this section, we review the relevant empirical and theoretical studies in India and abroad. Promoting entrepreneurship constitutes an important part of the Lisbon agenda and the Europe 2020 strategy which treats entrepreneurship as a key component of smart, sustainable and inclusive growth. Entrepreneurship is perceived by policy-makers as a means of tackling labour market disadvantage and social exclusion more generally (De Clerq and Honig 2011), although others regard reliance on such options as over-optimistic, at least for some groups (Kitching 2006; Blackburn and Ram 2006). Entrepreneurship Development Institute of India (EDI-I) has been inspired, in which five components including; need for independence, risk taking, need for achievement, internal locus of control and creativity are being considered as people's entrepreneurial attitude characteristics (Karimi et al., 2014). An appreciative process of facilitating a deeper understanding of the needs of disabled youth would assist service providers to reconceptualise disability within an expansive framework of equal opportunities and active citizenship (Lieketseng Ned et al., 2016). Entrepreneurship is becoming a most popular employment alternative for PWDs. Business ownership has long appealed to them. Practical considerations are a flexible schedule, independence, and a work environment fitted to their needs, e.g., a 
home-based business (Angelocci et al., 2008). Support ought to be artistic, flexible and shared with employers. Support will come from service professionals, self-advocacy teams, co-workers, managers, supervisors and/or home networks (Stevens et al., 2007). While helping the disabled individuals to become self-employed or start new businesses, there is a need to weigh the opportunity costs. Policy-makers might consider that the highly resource-intensive, tailored forms of support recommended here are too costly to contemplate given competing priorities (Kitching, 2014).

A national non-profit organisation that has been created to help disabled entrepreneurs maximise their potential in the business world is Business people Overcoming Limitations from Disabilities (BOLD). It provides resources, consulting services and training for organisations that want to start, modify or expand entrepreneurship programs for people with disabilities (Galle and Kenneth, 2009). Disabled people's economic activities can empower them financially and allow them to escape from unemployment or entitlements-based programmes to self-employment (Hwang and Roulstone, 2014) As with all forms of entrepreneurship, there are 'push' and 'pull' factors influencing the decision to start one's own business. Undoubtedly, the discrimination faced by PWDs in terms of employment and earnings opportunities encourages many to become self-employed (Cooney, 2008). Entrepreneurs can play a critical role bringing in movement actors and organisation as they are often required to mobilise outsiders for support (Pettinicchio, 2013). In entrepreneurship, is sometimes difficult to determine the common needs of disabled entrepreneurs, because of the varieties in disability means, i.e. sensory impairments, physical impairments, etc. Disabled people have the same opportunities to be an entrepreneur, perhaps they need some support to promote their unique and individual business needs (Hasan, 2014).

\subsection{Objectives of the Study}

The study aims to create an awareness among PWDs about the entrepreneurial opportunities available to them. It also describes the role of Ministry of Social Justice and Empowerment (MSJE) in promoting entrepreneurship among differently abled persons.

\subsection{Methodology}

The present study has focused on opportunities of disabled entrepreneurs in Indian social welfare schemes which consist of NHFDC, DDRS, Skill training through the national institutes and SIPDAs. The study is based on secondary data. The data has been collected from report on India stat, NHFDC and Ministry of Social Justice and 
Empowerment in India. Research articles relating to disabled entrepreneurs published in different reputed journals, magazines, newspaper and periodicals were also been sourced. The e-views software is used to analyse the data.

\subsection{Schemes for Disabled Persons}

This section summarises some of the schemes that exist to provide different kinds of support to persons with disabilities. The information source for these schemes is the Ministry of Social Justice and Empowerment (MSJE).

(i) NHFDC: In 1997, the Government set up a Corporation named National Handicapped Finance and Development Corporation (NHFDC) under the administrative control of the Ministry of Social Justice and Empowerment for providing financial assistance at concessional rate of interest to PWDs for self-employment. This Corporation also gives skill training grant for Skill Training and Entrepreneurship of PWDs wherein it provides $100 \%$ of the total recurring cost of the training programme to the training institutes/organisations. NHFDC also provides stipend at the rate of Rs.2000/- per month to the disabled trainees during the training period. The training duration ranges from one month to six months. The NHFDC provided funds for training programmes through the DDRS and SIPDA schemes and also by internal resources of the Corporation.

(ii) Deendayal Disabled Rehabilitation Scheme (DDRS): Under Deendayal Disabled Rehabilitation Scheme (DDRS), Vocational Training Centre projects are given financial assistance (up to $90 \%$ of the project cost) for skill up gradation of PWDs. These are meant for the age group of 15-35 years to provide skills to enable such persons to move towards economic independence.

(iii) Skill training through the National Institutes: The seven National Institutes (NIs) under the administrative control of Department of Disability Affairs also organise Vocational Training Programmes for the PWDs in their respective field of disability for appropriate trades.

(iv) SIPDA (Scheme for Implementation of Persons with Disabilities (Equal Opportunities, Protection of Rights and Full Participation) Act, 1995): Under this scheme, financial assistance is provided to State Governments and to autonomous organisations/Institutions under Central or State Governments, for various activities relating to implementation of Persons with Disabilities Act, 1995. Under this scheme grant-in-aid is provided for the skill development programmes for PWDs with effect from the year 2013-14. 
(v) Vocational Rehabilitation Centre for Handicapped (VRCs): The Ministry of Labour \& Employment has set up 21 VRCs for Handicapped at different parts of the country. The main objective of these centres is to impart non-formal vocational training and extend vocational rehabilitation assistance to PWDs as per their residual capacities with a view to assist them to lead an independent and productive life in society.

\subsection{Opportunities for Self-employment of Different Abled Persons}

The corporation can assist a wide range of income regenerating activities. Infrastructure development schemes alone will not qualify for financing unless it leads directly to income generation. For a disabled person whose family income is below Rs.22, 000/- p.a for rural areas and Rs.24, 000/- p.a for urban areas (living below the income/economic criteria), the proposals should be acceptable.

\subsection{Self-employment in small business}

Loan will be provided for self-employment of PWDs in service sector or for trading activity. The Small Business project or activity for which financial assistance has been sought, will have to be operated by the disabled person and employing at least $15 \%$ PWDs in the venture. The maximum loan available is Rs.2.50 lakh. The indicative areas of financing are the following:

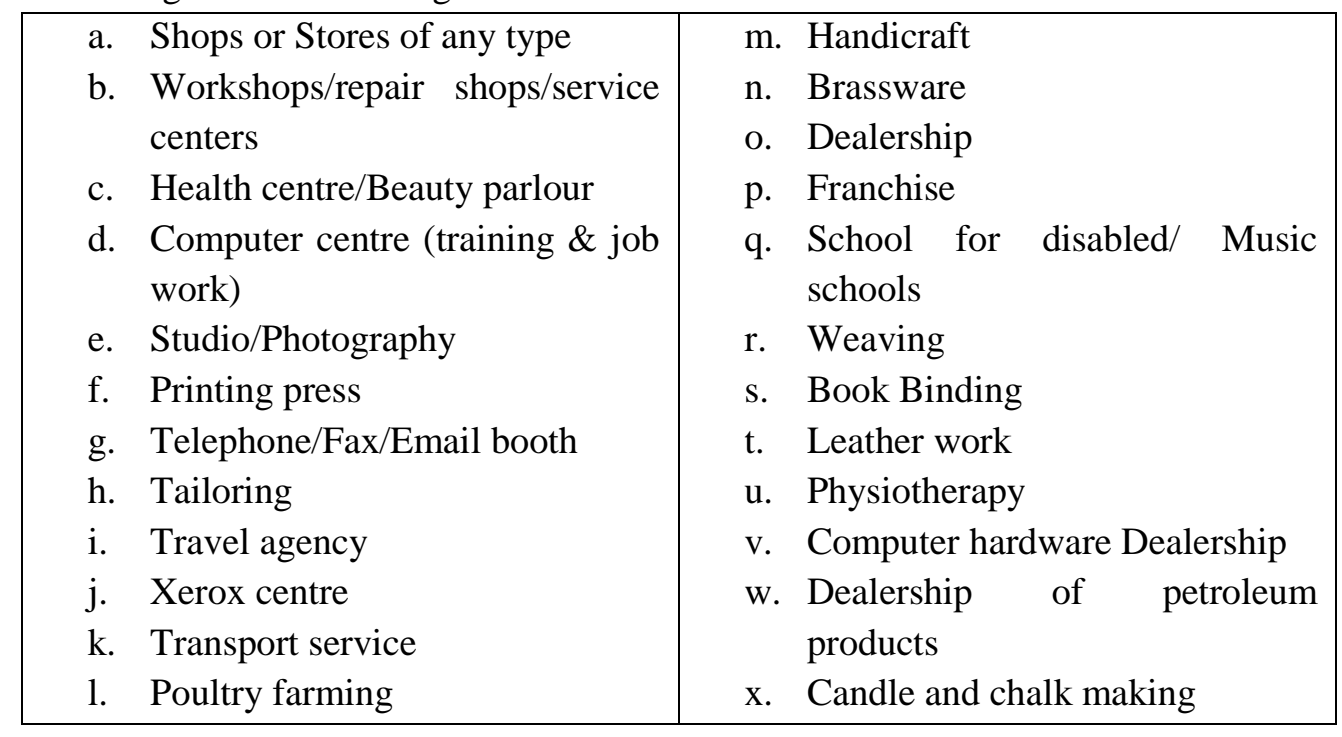

\subsection{Assistance to disabled entrepreneurs}

Loan may be provided for manufacturing, fabrication and production activity. The disabled person will be the owner/chief executive of the company and employing at 
least $15 \%$ disabled persons. The maximum amount of loan provided under the scheme is Rs.20 lakh. An illustrative list of activities is given below.

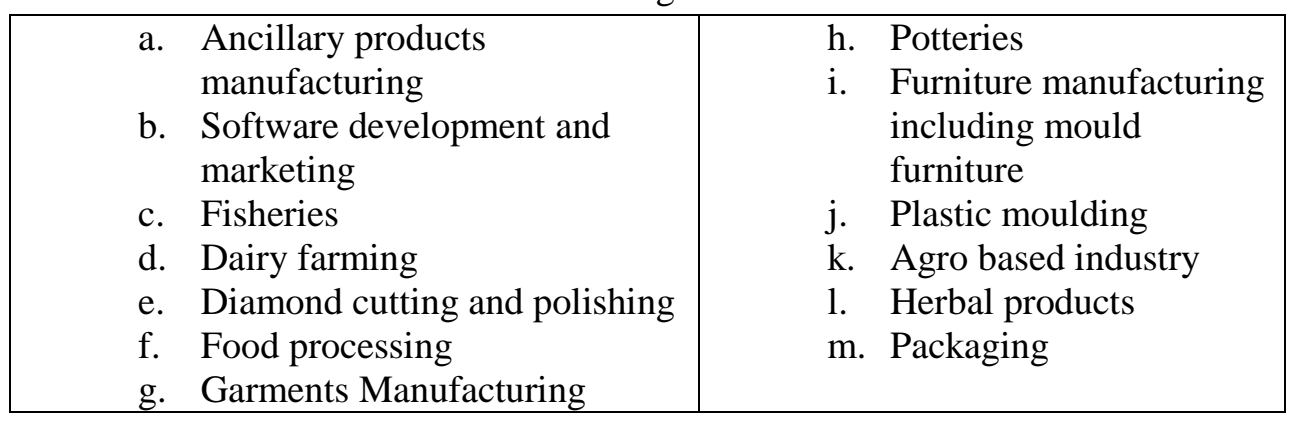

\subsection{Assistance for agricultural activities}

Loan assistance is provided to disabled persons for:

a. Agriculture production and related field such as irrigation, purchase of agriculture machinery, horticulture, sericulture etc.

b. Purchase of equipment for agriculture services such as custom service (pesticide, spray, harvesting etc.) custom hiring of agriculture machinery.

c. Agriculture marketing (through co-operative societies/Association of disabled farmers), Setting up grading and packing houses, purchase of transport vehicles for marketing of agriculture produce etc.

d. Purchase of land for agriculture purpose by individual disabled person or by cooperative societies of disabled persons.

e. Commission agents at Mandi Samities.

f. Small business such as retail outlets for marketing Organic fertilizers, Pesticides/insecticides. Improved variety of seeds, farm machinery etc. Maximum loan available under this scheme is Rs.5.00 lakh.

\subsection{Scheme to promote manufacturing/production of assistive devices for disabled persons}

Loan Assistance is provided for setting up small scale industry for manufacturing aids and appliances developed under $R \& D$ programmes of government/academic institutions of repute for disabled within the country. The company should employ disabled persons. The maximum loan available under this scheme is Rs.25 lakh.

\subsection{Assistance for skills and entrepreneurial development programmes}

a. Financial assistance in the form of loan is provided to the channelizing agencies, reputed NGO's, RRTC's and recognized technical institutions for imparting skills 
and entrepreneurial development training to disabled persons. Financial assistance is also provided for setting up vocational training centres including computer training centre, exclusively for imparting skills and entrepreneurial development training to PWDs.

b. The proposals for loan should necessarily indicate placement/self-employment opportunities to the disabled after training.

c. Financial assistance in the form of loan will also be available for upgradation of skills of disabled workers and entrepreneurs who have set up units with the financial assistance from NHFDC.

\subsection{Scheme to promote self-employment amongst persons with mental retardation, cerebral palsy and autism}

Persons with mental retardation, cerebral palsy or autism may not be eligible to seek loan and enter into a legal contract. In such cases following categories of persons are eligible for financial assistance from NHFDC.

a. Parents of dependent mentally retarded persons.

b. Spouse of dependent mentally retarded persons.

Persons seeking loan from NHFDC under this category should encourage selfemployment of the mentally retarded persons. Projects should be identified in such a way that there is direct involvement and participation of the beneficiary in the project. Maximum loan available under this scheme is Rs.2.50 lakhs. Indicative areas for financing are:

- Shop or store

- Assembling unit

- Workshop or repair shop

- Envelop making unit

- Pickle, papad, wadi making unit

- Home unit for making squash, jam etc.

- Bakery

- Xerox Centre
- Tailoring unit

- DTP Centre

- Screen Printing

- Poultry

- Dairy Farming

- Horticulture

- Handloom Unit

- Block, textile printing

\subsection{Challenges based by entrepreneurial person with disabilities (EPWDs)}

In addition to facing the general challenges to business start-up, new business is loaded with difficulties, whether one is disabled or non-disabled. Indeed the types of enterprises started by people with disabilities are as varied as those started by any other 
section of people, and their business problems are broadly very similar to those of other enterprises. The major challenges of entrepreneurial persons with disabilities have been discussed below.

(i) Lack of confidence and limited aspirations: Differently abled people might have issues identifying entrepreneurial opportunities and growing their commercial enterprise idea. There are also problems engaging with the available guide infrastructure in a meaningful way, which contributes to low ranges of self-assurance associated with small commercial enterprise strolling. This is further compounded through the unsupportive function of family and friends who frequently discourage start-ups.

(ii) The benefits trap: The entrepreneurial PWDs is often a fear of dropping the safety of regular gain income whilst other profit is generated. Awareness of eligibility for benefits is incomplete in a number of the people with disabilities that contributes to perceptions of self-employment as 'risky'.

(iii) Lack of relevant enterprise knowledge and skills: Differently abled individuals regularly lack expert commercial enterprise control, prison and economic capabilities and knowledge because of limited relevant training and employment.

(iv) Access to start-up capital: PWDs often experience problems financing new business because of limited personal economic sources (savings, home ownership), which are, in part, because of bad schooling and the concentration of disabled employees in low-paid occupations; bad credit rating after long-term gain receipt; disinterest/ discrimination at the part of banks; and loss of available statistics on assets of presents and loans.

(v) Consumer discrimination: Self-employment may be deterred by purchaser discrimination, decreasing demand for goods and services produced, as well as the rewards to self-employment.

(vi) Increased labour expenses: A few entrepreneurs with disabilities may need assistants to help them undertake tasks that people without disabilities can do on their own (e.g. transferring merchandise, inputting facts into computer software program), which will increase their labour expenses and puts them at a competitive drawback.

(vii) Lack of appropriate business aid services: This barrier has some dimensions that relate to the individual nature of their disabilities.

- Business advisors are frequently reluctant to endorse self-employment as a career choice for disabled human beings and sometimes actively try to dissuade them. Such views might be a result of advisors' inadequate or stereotypical understandings of the restrictions arising from unique situations and misperceptions of aid recipients' abilities.

- Training isn't always continually tailored to individual needs and consequently is of restricted value to programme recipients. 
92 | MANTHAN: Journal of Commerce and Management, Volume 3, Issue 2

- Support services might not be available specially formats (e.g. Braille), which makes the assist service inaccessible for sure segments of the population of people with disabilities. This may also affect the attention stage of available supports.

- Premises wherein help is provided won't be reachable for people with conditions and impairments that impact their mobility. Moreover, this barrier can be multiplied by way of challenges related to shipping from help centres for those with mobility challenges.

- Support programmes may also use language that is off setting to humans with disabilities. For example, marketers who enjoy disability frequently have lower growth aspirations and may not identify with phrases which includes 'entrepreneur' due to the fact they do not see themselves as exploiting any possibility of being innovative.

- The range of impairment and incapacity may be such that some disabled marketers might not understand themselves as 'disabled' and like to be supported beneath mainstream, instead of disability-specific, services.

\subsection{Results and discussion}

This paper analyses the entrepreneurial opportunities of differently abled persons and status of the entrepreneurship. Based on the Ministry of Social Justice \& Empowerment 1997, nationwide survey has been conducted bi-annually by the schemes to examine the nature of disability enterprises and to support the growth of their own businesses since 2011. Data were drawn from the year 2011 to 2015 (Table 1). It offer insights into the extent of which disabled entrepreneurs are starting up and running their own business.

Table 1: PWDs availing Financial Assistance for Creating Self-Employment in India

\begin{tabular}{|c|c|c|c|c|}
\hline Years & $\begin{array}{c}\text { No of PWDs under } \\
\text { NHFDC }\end{array}$ & $\begin{array}{c}\text { No. of PWDs } \\
\text { trained by NIs }\end{array}$ & $\begin{array}{c}\text { Beneficiaries } \\
\text { of SIPDA }\end{array}$ & $\begin{array}{c}\text { Trainees of } \\
\text { VRC }\end{array}$ \\
\hline $2011-12$ & 11129 & 756 & NIL & 11588 \\
\hline $2012-13$ & 13296 & 5151 & NIL & 12621 \\
\hline $2013-14$ & 13312 & 5756 & 570 & 11928 \\
\hline $2014-15$ & 14703 & 2413 & 9000 & - \\
\hline Total & 52440 & 14076 & 9570 & 40437 \\
\hline
\end{tabular}

Source: indiastat, NHFDC 
The majority of PWDs are getting economic assistance from the NHFDC for self-employment. In 2014-15, there were more beneficiaries compared to preceding years. The highest populations of PWDs was in the state of Andhra Pradesh compared to the other south Indian states, the next one is Karnataka and third one is Tamil Nadu. The eight distinctive disabilities listed with the Ministry of Social Welfare Empowerment have been shown in Table 2. The state government will create the attention and motivation for self-employment programme suitable for small commercial enterprises particularly those of PWDs. Table 3 shows the State-wise details of funds provided and number of beneficiaries trained during the last four years by NHFDC.

Table 2: State-wise Population of Different Types of Disabled Persons

\begin{tabular}{|c|c|c|c|c|c|c|c|c|c|}
\hline States & 串 & . & 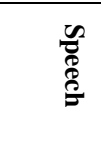 & 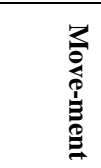 & 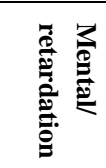 & 蒿总 & $\begin{array}{l}\stackrel{Z}{\Xi} \\
\stackrel{9}{9} \\
\stackrel{9}{9}\end{array}$ & 总 & $\stackrel{\overrightarrow{0}}{\stackrel{\theta}{0}}$ \\
\hline $\begin{array}{l}\text { Andhra } \\
\text { Pradesh }\end{array}$ & 398144 & 334292 & 219543 & 538934 & 132380 & 43169 & 409775 & 190370 & 2266602 \\
\hline Karnataka & 264170 & 235691 & 90741 & 271982 & 93974 & 20913 & 246721 & 100013 & 1324205 \\
\hline Kerela & 115513 & 105366 & 41346 & 171630 & 65709 & 66915 & 96131 & 99233 & 761843 \\
\hline Pondicherry & 3608 & 6152 & 1824 & 9054 & 2335 & 853 & 4137 & 2226 & 30189 \\
\hline Tamil Nadu & 127405 & 220241 & 80077 & 287241 & 100847 & 32964 & 238392 & 92796 & 1179963 \\
\hline
\end{tabular}

Table 3: State-wise details of fund provided and number of beneficiaries trained during the last four years (NHFDC)

\begin{tabular}{|c|c|c|c|c|c|c|c|c|}
\hline \multirow{2}{*}{ 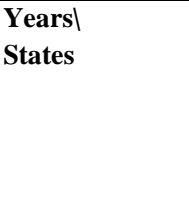 } & \multicolumn{2}{|c|}{ 2011-12 } & \multicolumn{2}{|c|}{ 2012-13 } & \multicolumn{2}{|c|}{ 2013-14 } & \multicolumn{2}{|c|}{ 2014-15 } \\
\hline & 氞 & 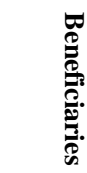 & 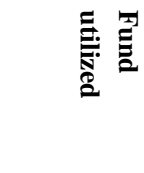 & 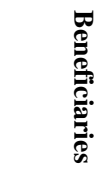 & 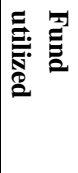 & 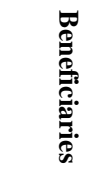 & $\underset{\text { 胥 }}{ }$ & 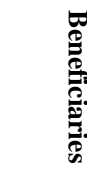 \\
\hline Andhra Pradesh & 0 & 100 & 1.5 & 29 & 4.92 & 60 & 0 & 453 \\
\hline Karnataka & 4.11 & 40 & 0.24 & 0 & 0 & 120 & 9.84 & 470 \\
\hline Kerala & 0 & 44 & 0 & 0 & 3.06 & 0 & 0 & 85 \\
\hline Pondicherry & 0 & 0 & 68 & 2.64 & 0 & 0 & 0 & 0 \\
\hline Tamil Nadu & 0 & 160 & 4.56 & 120 & 4.26 & 50 & 1.89 & 200 \\
\hline
\end{tabular}

Source: $N H F D C$ 
As compared to commercial enterprises, disability businesses are predominantly small and medium organisations that do not require a massive quantity of start-up cost, knowledge and competencies consisting of shops, production devices and accommodation carriers. They begin their establishments with many difficulties, and find it difficult to sustain the business financially maintain without the support of the authorities. The government provides fund to the various schemes; however, for the purpose of our study, we have focused on the scheme NHFDC.

Table 4 looks at the funds that have been provided to the various South Indian states by VTC under DDRS. The maximum number of beneficiaries have been from the state of Andhra Pradesh. The Tamil Nadu regime used the fund properly from the year 2011 to 2014. Tamil Nadu has seen its beneficiaries go down and has improved its awareness drive for the disabled entrepreneurs that could increase entrepreneurship.

Table 4: State-wise details of fund provided and number of beneficiaries trained during the last four years (VTC under DDRS)

\begin{tabular}{|c|c|c|c|c|c|c|c|c|}
\hline \multirow{2}{*}{ 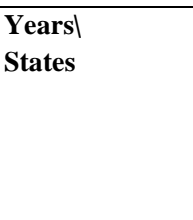 } & \multicolumn{2}{|c|}{ 2011-12 } & \multicolumn{2}{|c|}{$2012-13$} & \multicolumn{2}{|c|}{ 2013-14 } & \multicolumn{2}{|c|}{ 2014-15 } \\
\hline & 吾 & 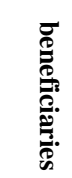 & 焉 & 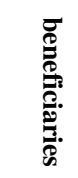 & 吾 & 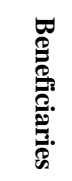 & 旡 & 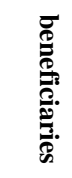 \\
\hline Andhra Pradesh & 647.08 & 7086 & 235.8 & 3432 & 442.56 & 5560 & 239.06 & 3608 \\
\hline Karnataka & 152.24 & 1357 & 31.58 & 490 & 53.28 & 976 & 0 & 0 \\
\hline Kerala & 205.74 & 1921 & 65.16 & 864 & 142.44 & 1495 & 40.16 & 734 \\
\hline Pondicherry & 0 & 0 & 0 & 0 & 0 & 0 & 0 & 0 \\
\hline Tamil Nadu & 85.61 & 1083 & 4.56 & 120 & 72.95 & 776 & 12.54 & 267 \\
\hline
\end{tabular}

Table 5 shows the state-wise population and entrepreneurs who are differently abled. The population of disabled persons is very high in the state of Andhra Pradesh but at the same time, differently abled entrepreneurs were also high in this state. The union territory of Pondicherry saw less disabled population and less entrepreneurs as well.

\subsection{Recommendations}

There is a need to make available information/signposting offerings - making publicly funded records services, online and offline available to as wide a group of people as possible. As authorities assisted services have increasingly moved to online platforms, the design of presidency websites is very crucial. 
Table 5: State wise Total Population and EPWDS

\begin{tabular}{|l|c|c|}
\hline \multicolumn{1}{|c|}{ States } & Population & EPWDs \\
\hline Andhra Pradesh & 2266602 & 20328 \\
\hline Karnataka & 1324205 & 3453 \\
\hline Kerala & 761843 & 5143 \\
\hline Pondicherry & 30189 & 68 \\
\hline Tamil Nadu & 1179963 & 2776 \\
\hline
\end{tabular}

There is a need to have flexible but at ease incapacity blessings - policy must ensure that aspiring disabled marketers go through no advantage penalty while taking over self-employment or beginning a enterprise. Transitions among labour marketplace status (employment, self-employment, unemployment, inaction) must be as seamless as possible. There is a need to offer safeguards at some stage in the early start-up phase while enterprise revenues can be confined. Should new business ventures cease trading, a swift return to blessings must be guaranteed.

Business advisor training can be carried out where advisors can be trained to present appropriate recommendation to exclusive organisations. Advisors have to receive training on range issues and keep away from stereotyping disabled customers on the premise of their impairments. Building clients' self-belief may be the exceptional aid advisors can provide.

There is also a need to increase awareness about the feasibility of entrepreneurship and develop entrepreneurship skills. They is a need to support the development of entrepreneurship, acquisition and use of assistive technology and make certain that PWDs get access to appropriate financial support from the authorities. Internet and IT accessibility should be increased with a view to motivate the commercial enterprise going to next level.

\subsection{Conclusion}

Most research papers on disability enterprises have focused on the economic outcomes and success. This paper focuses on opportunities in disability entrepreneurship and how disabled people's lives need to be fashioned by what they can do instead of what they cannot do. However, disability enterprises, unlike many commercial enterprises, are more likely to be home-based and small in nature. Many of them have 
been pushed into starting up business because their disabilities practically disqualifies them from other forms of employment. The biggest hurdles of disabled entrepreneurs may be the misconceptions about disabled people's capabilities as business owners. In policy terms, the limited impact of the paternalist quota and sheltered self-employment schemes overlaid with rather dilute legal rights contained in the India's NHFDC leaves disabled people under-supported in both mainstream employment and entrepreneurship development. The is a need to further support access and sustenance of enterprise - for example through clear-finance, training, market advantage, take-off incentives/subsidies and human resource expertise. More policy support for Indian disabled small business ventures is needed. Despite obstacles, the positive relationships between disabled people's firms, employability and economic growth should be acknowledged. Especially, we argue that the success of disability entrepreneurs needs to be reconsidered not only as income and profits but also as independence, participation and inclusion in society, engaging meaningful work and increasing well-being. It is important to recognise that simply encouraging disabled people to start business will have little effect. What is needed is policy that considers accessibility to and the sustainability of self-employment enterprises.

\section{References}

Alhuei, G., Karimi, A., \& Alizadeh, M. (2014). Entrepreneurial attitude in students with hearing disabilities (The Iranian experience). Asian Journal of Research in Business Economics and Management, 4(10): 262.

Angelocci, R. M., Lacho, K. J., Lacho, K. D., \& Galle, W. P. (2008). Entrepreneurs with disabilities: Role of assistive technology, current status and fuuture outlook. Proceedings of the Academy of Entrepreneurship, 14(1): 1-5.

Arnold, N. \& Seekins, T. (2002). Self-employment: A process for use by vocational rehabilitation agencies. Journal of Vocational Rehabilitation, 17: 107-13.

Blanck, P.D , Slander, L.A., Schmeling, J. L., \& Schartz, H. A. (2003). The emerging workforce of entrepreneurs with disabilitiles- prelimaniary study of entrepreneurship in IOWA. Iowa Law Review, 85(5).

Cooney, T. (2008). Entrepreneurs with Disabilities: Profile of a Forgotten Minority . Irish Business Journal, 4(1): 119-129. 
De Clerq, D. \& Honig, B. (2011). Entrepreneurship as an integrating mechanism for disadvantaged persons. Entrepreneurship and Regional Development, 23(5-6): 353-372.

Diochon, M., Durepos, G., \& Anderson, A. R. (2011). Understanding Opportunity in Social Entrepreneurship as Paradigm Interplay. Social and Sustainable Entrepreneurship (Vol. 13). Emerald Group Publishing(EGP)Ltd.

Galle Jr, W. P., \& Lacho, K. J. (2009). A model for self-employment training for people with disabilities. Academy of Health Care Management Journal, 5(1/2): 53-59.

Hwang, S. K., \& Roulstone, A. (2015). Enterprising? Disabled? The status and potential for disabled people's microenterprise in South Korea. Disability \& Society, 30(1): 114129.

Johnmark, D. R., Munene, J. C., \& Balunywa, W. (2016). Robustness of personal initiative in moderating entrepreneurial intentions and actions of disabled students. Cogent Business \& Management, 50(1): 1-16.

Karimi, A., \& Mobaraki, M. H. (2012). The significance of emotional intelligence on entrepreneurial behavior of instructors (Case study: Iran Technical and vocational Training Organization (TVTO)'s Instructors). International Journal of Business and Social Research (IJBSR), 2(5): October.

Kitching, J. (2006). Can small businesses help reduce employment exclusion? Environment and Planning C: Government and Policy, 24(6): 869-884.

Kitching, J. (2014). Entrepreneurship and self-employment by people with disabilities. Background Paper for the OECD Project on Inclusive Entrepreneurship.

Meager, N. \& Higgins, T. (2011). Disability and Skills in a Changing Economy. UK Commission for Employment and Skills, Briefing Paper Series, online at: http://www.oph.fi/download/140962 equality-disability.pdf

Naheed, N. R. (2014). Support Service Providers for Disabled Entrepreneurs. Journal of Business Studies, 1: 1-26.

Ned, L., \& Lorenzo, T. (2016). Enhancing the public sector's capacity for inclusive 
98 | MANTHAN: Journal of Commerce and Management, Volume 3, Issue 2

economic participation of disabled youth in rural communities. African Journal of Disability, 5(1): 1-9.

Pettinicchio, D. (2013). Strategic action fields and the context of political entrepreneurship: How disability rights became part of the policy agenda. Research in Social Movements, Conflict and Change (Vol. 36). EGP Ltd. 1108 / S0163-786X

Ruggeri Stevens, G., \& Goodwin, S. (2007). "Learning to work" in small businesses. Education Training, 49(8/9): 745-755. 